\title{
ANALISIS EFISIENSI TEKNIS PENERAPAN PENGENDALIAN HAMA TERPADU (PPHT) SKALA KAWASAN PADA TANAMAN PADI (Oryza sativa L) DI PADEMAWU BARAT, PAMEKASAN TECHNICAL EFFICIENCY ANALYSIS OF IMPLEMENTATION INTEGRATED PEST CONTROL SCALE OF AREA AT PLANT PADI (Oryza sativa L) IN PADEMAWU BARAT, PAMEKASAN
}

\author{
Mohammad Shoimus Sholeh ${ }^{1}$, Kustiawati Ningsih ${ }^{2}$, Henny Susilawati ${ }^{3}$ \\ ${ }^{1,2}$ Dosen, Fakultas Pertanian Universitas Islam Madura \\ ${ }^{3}$ Penyuluh Pertanian, Dinas Tanaman Pangan, Hortikultura dan Perkebunan Kab.Pamekasan \\ moh.shoimus@gmail.com
}

\begin{abstract}
The application of management integrated pest scale area is a solution in the problems of organisms bully plant scale area and the management of synergism strategy pest by farmers in the same region so contribute real measurable against the program of farming production rice. The application of management integrated plant scale must be efficient area technically in order to get rice production maximum. The farmer can improve production and rice productivity by using the production factors efficiently. The objectives of the research are analyze the production factors which affect the rice farming and analyze of technical efficiency of rice farming. The stochastic frontier is used in this research to analyze technical efficiency. From the frontier analysis will be obtained the factors which give impact to the rice farming organic fertilizer, chemical fertilizers, botanical pesticides and chemical pesticides. The average of technical efficiency is 0,93, it means the farmers are attains $93 \%$ of production from the potential production of rices and there is still $7 \%$ to improve rice production. Within the value of average technical efficiency is 0,93 will be obtained the income of this farming is $R p$. 22.332.779,- per hectare in once growing season.
\end{abstract}

Keywords: intregeted pest management, factor of productions, stochastic frontier, efficiency.

\begin{abstract}
ABSTRAK
Penerapan Pengelolaan Hama Terpadu (PPHT) Skala Kawasan, merupakan salah satu solusi dalam penanganan permasalahan Organisme Pengganggu Tanaman (OPT) Skala Kawasan, dan terjadinya sinergisme strategi pengelolaan OPT, oleh petani dalam kawasan yang sama, sehingga memberikan kontribusi yang nyata, dan terukur terhadap program penanganan produksi usahatani padi. Penerapan Pengelolaan Tanaman Terpadu (PPHT) skala kawasan harus efisien secara teknik, agar mendapatkan produksi padi maksimal. Petani masih dapat meningkatkan produksi dan produktivitas tanaman padi dengan penggunaan faktor-faktor produksi yang efisien, sehingga dapat meningkatkan pendapatan petani. Tujuan penelitian yaitu untuk menganalis faktor-faktor produksi yang berpengaruh terhadap produksi padi dan menganalisis tingkat efisiensi teknik penggunaan faktor-faktor produksi usahatani padi. Analisis yang digunakan yaitu stochastic frontier untuk menganalisis tingkat efisiensi teknis. Dari hasil analisis diperoleh faktor-faktor produksi yang berpengaruh nyata terhadap produksi usahatani wortel adalah pupuk organik, pupuk anorganik, pestisida nabati dan pestisida kimia. Rata-rata tingkat efisiensi teknis sebesar 0,93 , berarti petani sudah mencapai produksi $93 \%$ dari potensial produksi padi dan masih terdapat $7 \%$ untuk meningkatkan produksi padi. Dengan tingkat efisiensi sebesar 0,93 diperoleh pendapatan usahatani padi sebesar Rp. 22.332.779,-- per hektar dalam satu musim tanam. Hal ini menunjukkan bahwa petani masih dapat meningkatkan pendapatan usahatani padi dengan meningkatkan efisiensi teknis.
\end{abstract}

Kata kunci: pengendalian hama terpadu, faktor produksi, stochastic frontier, efisiensi. 


\section{PENDAHULUAN}

Padi merupakan sumber pangan bagi penduduk Indonesia, yang mana sebagian besar dibudidayakan sebagai padi sawah. Padi merupakan komoditas utama dalam menyokong pangan untuk memenuhi kebutuhan hidup penduduk. Indonesia sebagai negara dengan jumlah penduduk yang besar menghadapi tantangan untuk memenuhi kebutuhan pangan penduduk (Anggraini, Suryanto, dan Aini, 2013). Untuk memenuhi kebutuhan pangan terutama beras maka diperlukan upaya dalam peningkatan produksi beras. Akan tetapi saat ini terganjal oleh berbagai kendala, seperti serangan hama penyakit, penyimpangan iklim, penurunan kualitas sumberdaya lahan, kualitas sumber daya manusia dalam hal pengetahuan peningkatan produksi padi sehingga berdampak terhadap penurunan produktivitas padi.

Penerapan Pengelolaan Hama Terpadu (PPHT) Skala Kawasan merupakan kegiatan pemberdayaan dan pendayagunaan petani alumni dan petani non alumni SLPHT yang diharapkan dapat memberikan solusi dalam penanganan permasalahn OPT Skala Kawasan dan terjadinya sinergisme strategi pengelolaan OPT oleh petani dalam kawasan yang sama, sehingga memberikan kontribusi yang nyata dan terukur terhadap program penanganan produksi. Kegiatan Penerapan Pengendalian Hama Terpadu (PPHT) Skala Kawasan ini dialokasikan kepada Kelompok Tani yang biasa melakukan penananam padi dua kali dalam satu tahun. Prinsip PHT adalah penggunaan tanaman sehat, pelestarian musuh alami, pengamatan mingguan, dan petani sebagai ahli PHT. Upaya dalam pelaksanaan prinsip PHT salah satunya melakukan pelestarian musuh alami dengan memberikan habitat dan menyediakan makanan bagi musuh alami yaitu bisa berupa rumput-rumputan dan vegetasi lain pada habitat lahan padi (Karindah, Purwaningsih, dan Agustin, 2015).

Desa Pademawu Barat merupakan desa yang terletak di Kecamatan Pademawu Kabupaten Pamekasan dimana wilayah tersebut mayoritas ditanami padi dua musim dalam setahun. Kelompok Tani Dharma Bakti merupakan kelompok tani di Desa Pademawu Barat yang menerapkan kegiatan Penerapan Pengelolaan Tanaman Terpadu (PPHT) karena lahannya terdapat sistem irigasi teknis. Penerapan PHT salah satunya yaitu dengan penggunaan pestisida nabati. Teknologi yang dikembangkan untuk mengendalikan hama dan pertanaman padi didasarkan kepada konsep pengendalian hama terpadu (PHT) dengan mempertimbangkan ekosistem, stabilitas, dan kesinambungan produksi sesuai dengan tuntutan praktek pertanian yang baik (Good Agricultural Practices, GAP) (Effendi, 2009).

Penerapan Pengelolaan Tanaman Terpadu (PPHT) skala kawasan harus efisien secara teknik agar mendapatkan prouksi padi maksimal dengan tingkat pengguaan faktor-faktor produksi. Dalam pembangunan pertanian, teknologi penggunaan faktor-faktor produksi memegang peranan penting karena kurang tepatnya jumlah dan kombinasi faktor produksi mengakibatkan rendahnya produksi yang dihasilkan atau tingginya biaya produksi. Rendahnya produksi dan tingginya biaya pada akhirnya akan mengakibatkan rendahnya pendapatan petani (Rahayu dan Riptanti, 2010).

Penelitian sebelumnya yang telah dilakukan oleh (Firmana, Nurmalina, dan Rifin, 2016) tentang efisiensi teknis usahatani padi dengan menggunakan pendekatan data envelopment analysis (DEA) diketahui beberapa faktor produksi berpengaruh secara nyata terhadap efisiensi teknis akan tetapi tidak menampilkan nilai efisiensi teknis minimum, maksimum dan rata-rata, sedangkan dalam penelitian ini menggunakan fungsi produksi Stochastik frontier sehingga diketahui pula tingkatan efisiensinya.

Penelitian yang telah dilakukan oleh (Kartiasih dan Setiawan, 2019) tentang efisiensi teknis usahatani padi diketahui beberapa faktor produksi pupuk dan pestida tidak berpengaruh nyata akan tetapi tidak dipilah antara faktor produksi pupuk organik dan anorganik serta pestisida kimia dan nabati, sedangkan dalam penelitian ini faktor pupuk organik dan pestisida nabati dimasukkan karena mengaplikasikan PPHT yang juga berdampak terhadap produksi padi. Berdasarkan latar belakang di atas, maka tujuan penelitian ini adalah: (1) mengetahui 
faktor-faktor yang mempengaruhi produksi usahatani padi, (2) mengetahui efisiensi teknisPenerapan Pengendalian Hama Terpadu (PPHT) Skala Kawasan pada tanaman padi di Desa Pademawu Barat Kecamatan Pademawu Kabupaten Pamekasan.

\section{METODE PENELITIAN \\ Penentuan Lokasi}

Penentuan lokasi penelitian dilakukan secara sengaja (purposive) di Desa Pademawu Barat pada Kelompok Tani Dharma Bakti dengan dasar pertimbangan yakni lahan di lokasi tersebut terdapat irigasi teknis dan bisa menanam padi selama 2 musim dalam setahun.

\section{Penentuan Sampel}

Metode pengambilan sampel dengan menggunakan metode sensus. Metode sensus adalah cara pengumpulan data apabila seluruh populasi diselidiki satu persatu. Dalam penelitian ini populasi Kelompok Tani Dharma Bakti Desa Pademawu Barat yang mendapatkan program Penerapan Pengendalian Hama Terpadu (PPHT) Skala Kawasan sebanyak 30 orang, 1 orang petani sebagai petak Laboratorium Lapang (LL) dan sebanyak 29 orang sebagai petak petani. Dengan menggunakan metode sensus, maka semua populasi sebanyak 30 orang dijadikan sebagai sampel penelitian.

\section{Metode Analisis Data}

\section{Analisis Fungsi Produksi Stochastik frontier}

Suatu fungsi produksi frontier adalah suatu fungsi yang menunjukkan kemungkinan tertinggi yang mungkin dapat dicapai oleh petani dengan kondisi yang ada di lapangan, dimana produksi secara teknis telah efisien dan tidak ada cara lain untuk memperoleh output yang lebih tinggi lagi tanpa menggunakan input yang lebih banyak dari yang dikuasai petani (Darwanto, 2010). Model persamaan fungsi produksi frontier dituliskan sebagai berikut.

$$
\operatorname{Ln} Y=\beta_{0}+\beta_{1} \ln X_{1}+\beta_{2} \ln X_{2}+\beta_{3} \ln X_{3}+\beta_{4} \ln X_{4}+\beta_{5} \ln X_{5}+\beta_{6} \ln X_{6}+v_{i}-u_{i}
$$

Dimana $Y$ merupakan produksi tanaman padi $(\mathrm{kg}), \beta_{0}$ adalah konstanta, $\beta_{1}, \beta_{1}, \beta_{1}, \beta_{1}$, adalah koefisien faktor produksi, $X_{1}$ adalah penggunaan benih $(\mathrm{kg}), X_{2}$ adalah penggunaan pupuk organik $(\mathrm{kg}), \mathrm{X}_{3}$ adalah penggunaan pupuk anorganik $(\mathrm{kg}), \mathrm{X}_{4}$ adalah penggunaan pestisida nabati (liter), $\mathrm{X}_{5}$ adalah penggunaan pestisida kimia $(\mathrm{kg}), \mathrm{X}_{6}$ adalah penggunaan tenaga kerja $(\mathrm{HOK}), \mathrm{v}_{\mathrm{i}}$ adalah a symmetric, normally distributed random eror atau kesalahan acak model dan $\mathrm{u}_{\mathrm{i}}$ adalah one-side error term $\left(\mathrm{u}_{\mathrm{i}} \geq 0\right)$ atau efek inefisiensi teknis.

\section{Analsis Efisiensi Teknis}

Tingkat efisiensi teknis usahatani padi untuk petani ke-i dapat ditaksir dengan formulasi sebagai berikut (Rao dan Battese, 1998):

$$
\mathrm{TE}_{\mathrm{i}}=\frac{\mathrm{Yi}}{\mathrm{Yi} *}
$$

Dimana $\mathrm{TE}_{\mathrm{i}}$ merupakan efisiensi teknis yang dapat dicapai oleh petani ke-I, $\mathrm{Y}_{\mathrm{i}}$ adalah output aktual usahatani mina mendong $(\mathrm{kg} / \mathrm{ha})$ dan $\mathrm{Y}_{i}{ }^{*}$ adalah output potensial usahatani mina mendong ( $\mathrm{kg} / \mathrm{ha})$.

\section{Analisis Biaya, Penerimaan dan Keuntungan Usahatani}

Pendapatan usahatani padi adalah selisih antara penerimaan yang di dapat dengan total biaya yang dikeluarkan dalam satu musim tanam. Besarnya pendapatan usahatani dapat dihitung dengan menggunakan rumus sebagai berikut:

$\pi=\mathrm{TR}-\mathrm{TC}$

Dimana $\pi$ merupakan pendapatan (Rp), TR adalah total penerimaan usahatani (Rp) dan TC adalah total biaya usahatani (Rp). 


\section{HASIL DAN PEMBAHASAN}

\section{Faktor-Faktor Produksi yang Berpengaruh Terhadap Produksi Usahatani Padi}

Dalam penelitian ini model yang digunakan adalah fungsi produksi stochastic frontier dengan menggunakan parameter Maximum Likelihood Estimated (MLE). Model tersebut digunakan untuk menganalisis faktor-faktor yang mempengaruhi produksi padi. Berikut hasil pendugaan fungsi produksi dengan metode MLE.

Tabel 1. Hasil Estimasi Fungsi Produksi Stochastic Frontier Usahatani Padi dengan Penerapan Pengendalian Hama Terpadu (PPHT) Skala Kawasan Pendekatan Maximum Likelihood Estimation.

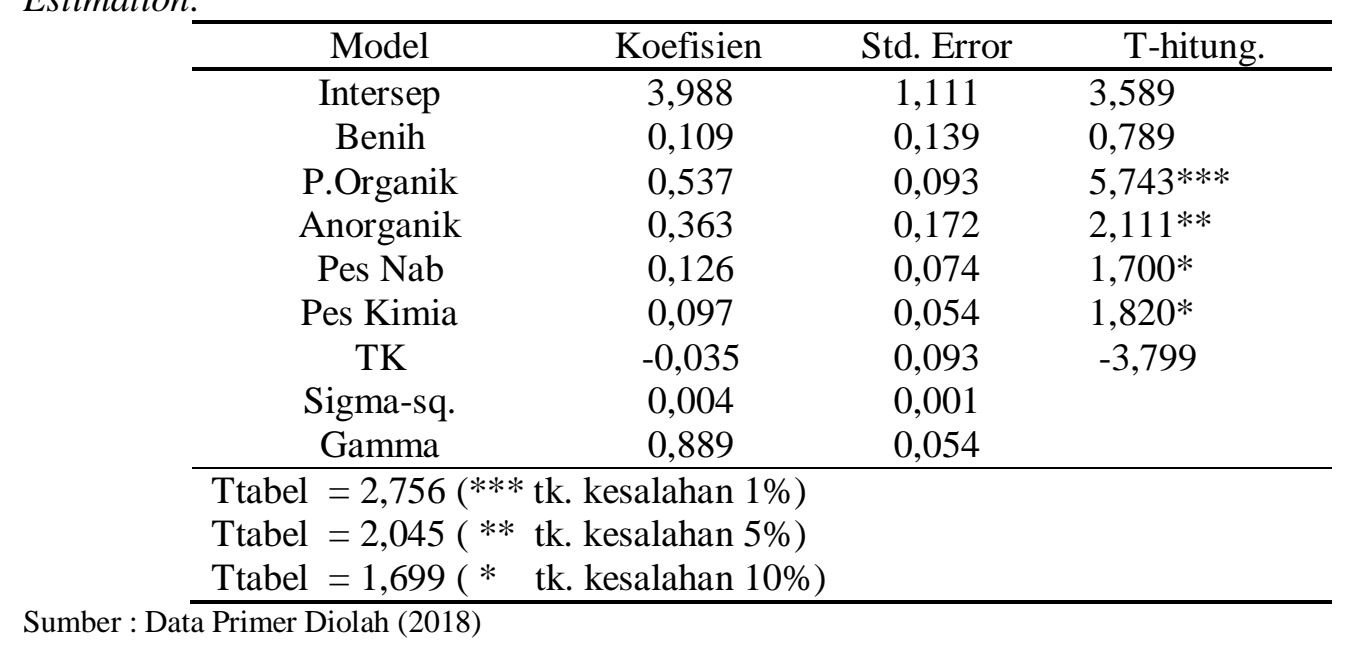

Faktor penggunaan benih secara statistik tidak berpengaruh nyata terhadap produksi padi dengan tingkat kesalahan $10 \%$. Jumlah penggunaan benih di daerah penelitian tetap berpengaruh terhadap produksi padi akan tetapi pengaruhnya sangat kecil dibandingkan dengan faktor yang lain. Penggunaan benih oleh masing-masing petani berbeda. Sebagian petani menggunakan benih baru dan sebagian lagi menggunakan benih hasil dari produksi tanaman padi. Hal ini menunjukkan bahwa tidak hanya dari segi jumlah penggunaan benih akan tetapi juga dari mutu benih yang digunakan sebagai bibit. Hasil penelitian yang dilakukan oleh (Kyei, Foli, dan Ankoh, 2011) menunjukkan bahwa penggunaan benih untuk usahatani kakau di Negara Ghana tidak berpengaruh nyata.

Faktor penggunaan pupuk organik berpengaruh nyata terhadap produksi padi dengan tingkat kesalahan 1\%. Hal ini menunjukkan bahwa semakin banyak pupuk organik yang digunakan, maka produksi padi semakin meningkat juga dengan penggunaan dosis pupuk sesuai dengan luas areal tanam. Pupuk organik yang digunakan oleh kelompok tani Dharma Bakti yaitu petroganik dan ppuk kandang. Dalam penelitian ini faktor yang berpengaruh terhadap produksi dengan tingkat kesalahan terendah yaitu penggunaan pupuk organik.

Faktor penggunaan pupuk anorganik berpengaruh nyata terhadap produksi padi dengan tingkat kesalahan 5\%. Nilai koefisien sebesar 0,36 artinya penambahan pupuk anorganik $1 \%$ akan mempengaruhi peningkatan produksi padi sebesar $0,36 \%$. Sesuai dengan hasil penelitian yang dilakukan oleh (Thamrin, 2016), diperoleh bahwa pupuk anorganik yang meliputi, Urea, Za dan NPK berpengaruh nyata terhadap produksi kopi arabika.

Faktor pengguanaan pestisida nabati berpengaruh nyata terhadap produksi padi dengan tingkat kesalahan $10 \%$. Hal ini menunjukkan semakin sering petani menggunakan pestisida nabati maka semakin besar produksi padi yang dihasilkan. Hasil penelitian yang dilakukan oleh (Sinaga, 2009), menunjukkan bahwa pestisida nabati dapat menekan serangan hama yang terdapat pada pertanaman kedelai sehingga kehilangan produksi dapat ditekan sekecil mungkin Faktor penggunaan pestisida kimia berpengaruh nyata terhadap produksi padi dengan tingkat 
kesalahan $10 \%$. Penggunaan pestisida bertujun untuk memberantas hama dan penyakit tanaman padi yang akan menurunkan produktivitas tanaman. Semakin sering penanggulangan dilakukan dengan penggunaan pestisida maka akan meminimalisir penurunan produksi. Menurut (Djojosumarto, 2008), pestisida merupakan zat kimia atau bahan lain serta jasad renik dan virus yang bisa digunakan untuk memberantas atau mencegah hama dan penyakit yang bisa merusak tanaman. Seperti pada hasil penelitian oleh (Wibisono dan Susilowati, 2011) dan (Ni'mah, Hariyati, dan Agustina, 2018) diperoleh hasil bahwa penggunaan pestisida berpengaruh nyata terhadap produktivitas tanaman.

Faktor penggunaan tenaga kerja tidak berpengaruh nyata terhadap produksi padi pada kelompok tani Dharma Bakti dengan tingkat kesalahan 10\%. Nilai koefisiennya bertanda negatif yang menunjukkan bahwa penggunaan tenaga kerja mulai dari pengolahan lahan sampai dengan panen relatif berlebihan. Penelitian yang dilakukan oleh (Mandei, 2015), menujukkan penggunaan tenaga kerja pada usahatani jagung di Kecamatan Remboken sudah berlebihan. Hal ini mengakibatkan nilai koefisien berdampak negatif terhadap produksi. Sejalan dengan penelitian yang dilakukan oleh (Setyawati dan Wibowo, 2019) menunjukkan bahwa penggunaan tenaga kerja tidak berpengaruh nyata terhadap produksi tebu.

\section{Analisis Efisiensi Teknis Usahatani Padi}

Tingkat efisensi teknis pada usahatani padi digunakan untuk mengetahui tingkat efisiensi tertinggi dan efisiensi terendah serta efisiensi rata-rata yang dicapai oleh petani pada kelompok tani Dharma Bakti dengan Penerapan Pengendalian Hama Terpadu (PPHT) Skala Kawasan. Tingkat efisiensi yang dicapai oleh petani dapat dilihat pada Tabel 2.

Tabel 2. Distribusi Frekuensi Efisiensi Teknis Usahatani Padi dengan Penerapan Pengendalian Hama Terpadu (PPHT) Skala Kawasan

\begin{tabular}{ccc}
\hline Tingkat Efisiensi & Jumlah Petani (orang) & Persentase (\%) \\
\hline $0.79-0.85$ & 4 & 13,33 \\
$0.86-0.91$ & 4 & 13,33 \\
$0.92-0.98$ & 22 & 73,34 \\
Jumlah & 30 & 100 \\
\hline
\end{tabular}

Sumber : Data Primer Diolah (2018)

Berdasarkan data Tabel 2, diketahui bahwa jumlah petani yang memiliki nilai efisiensi teknis terbanyak yaitu pada tingkat efisiensi teknis $0,92-0,98$ sebesar 22 petani padi. Hal ini menunjukkan bahwa masih ada kesempatan sebesar $8-2 \%$ untuk meningkatkan produksi padi. Perbedaan tingkat efisiensi bisa disebabkan oleh faktor tingkat kehadiran anggota kelompok tani dalam program penyuluhan yang dilaksanakan oleh petugas penyuluh karena dalam program tersebut petani diberi pelatihan teori dan praktek serta pendapingan dari petugas penyuluh. Petani sangat antusias dalam mengikuti program Penerapan Pengendalian Hama Terpadu (PPHT) dilihat dari rata-rata tingkat efisiensi petani diatas 0,9.

Tabel 3. Distribusi Efisiensi Teknis Usahatani Padi dengan Penerapan Pengendalian Hama Terpadu (PPHT) Skala Kawasan

\begin{tabular}{cc}
\hline Statistik & Tingkat Efisiensi \\
\hline Minimum & 0,79 \\
Maksimum & 0,98 \\
Rata-rata & 0,93 \\
\hline
\end{tabular}

Sumber : Data Primer Diolah (2018)

Dari Tabel 3 diketahui bahwa tingkat efisiensi teknik usahatani padi terendah yaitu sebesar 0,79 yang berarti bahwa responden pada tingkat efisiensi ini mampu mencapai $79 \%$ dari 
produksi potensial padi yang diperoleh dengan kombinasi penggunaan faktor-faktor produksi yaitu benih, pupuk, pestisida dan tenaga kerja dalam berusahatani padi. Sedangkan tingkat efisiensi tertinggi dari yaitu sebesar 0,98 . Hal ini menunjukkan bahwa petani dapat mencapai paling tidak 98\% dari potensial produksi padi yang diperoleh dengan kombinasi penggunaan faktor-faktor produksi dalam berusahatani padi di daerah penelitian. Rata-rata petani responden memiliki tingkat efisiensi teknis yang cukup tinggi yaitu sebesar 0,93 yang berarti rata-rata petani sudah mencapai produksi $93 \%$ dari potensial produksi padi dan masih terdapat $7 \%$ bagi rata-rata petani untuk meningkatkan produksinya.

\section{Analisis Usahatani Padi}

Pendapatan petani dipengaruhi oleh hasil produksi padi dalam satu musim tanam, harga padi dan total biaya untuk sewa lahan, penyusutan peralatan, biaya sarana produksi dan tenaga kerja yang digunakan mulai dari pengolahan lahan, penanaman, pemupukan, penyemprotan, penyiangan dan penjarangan dan panen dengan luasan 1 hektar dalam satu musim tanam. Pendapatan rata-rata yang diterima petani pada kelompok tani Dharma Bakti dapat dilihat pada Tabel 4.

Tabel 4. Pendapatan Usahatani Padi dengan Penerapan Pengendalian Hama Terpadu (PPHT) Skala Kawasan

\begin{tabular}{cc}
\hline Uraian & Biaya (Rp) \\
\hline Biaya Tetap & Rp. 5.922 .221 \\
Biaya Variabel & Rp. 12.385 .000 \\
Total Biaya & Rp. 18.307 .221 \\
Penerimaan & Rp. 40.640 .000 \\
Pendapatan & Rp. 22.332 .779 \\
\hline
\end{tabular}

Sumber : Data Primer Diolah (2018)

Pada Tabel 4. pendapatan yang diterima oleh petani rata-rata sebesar Rp. 22.332.779,- per hektar dalam satu musim tanam, sehingga usahatani padi pada kelompok tani Dharma Bakti di Desa Pademawu Barat Pamekasan menguntungkan.

\section{KESIMPULAN}

Faktor-faktor produksi yang berpengaruh nyata terhadap produksi usahatani padi dengan Penerapan Pengendalian Hama Terpadu (PPHT) skala kawasan yaitu penggunaan pupuk organik, pupuk anorganik, pestisida nabati dan pestisida kimia. Tingkat efisiensi teknik usahatani padi terendah sebesar 0,79 dan tingkat efisiensi tertinggi dari yaitu sebesar 0,98. Ratarata petani memiliki tingkat efisiensi teknis sebesar 0,93 yang berarti produksi tanaman padi dengan Penerapan Pengendalian Hama Terpadu (PPHT) skala kawasan mencapai 93\% dari produksi potensial tanaman padi dan masih terdapat $7 \%$ untuk meningkatkan produksinya. Dengan rata-rata efisiensi teknis sebesar 0,93 diperoleh pendapatan usahatani padi sebesar Rp. 22.332.779,-- per hektar dalam satu musim tanam. Hal ini menunjukkan bahwa usahatani padi pada kelompok tani Dharma Bakti di Desa Pademawu Barat menguntungkan dan petani masih bisa meningkatkan pendapatannya dengan meningkatkan efisiensi teknis. Perlu adanya penyuluhan tentang penggunaan benih karena penggunaan benih pada kelompok tani Dharma Bakti tidak berpengaruh nyata penggunaan benih tidak hanya dilihat dari segi kuantitas tapi mutu benih dan penggunaan benih yang berulang.

\section{DAFTAR PUSTAKA}

Anggraini, F., Suryanto, A., \& Aini, N. (2013). Sistem tanam dan umur bibit pada tanaman padi sawah (Oryza sativa L.) varietas Inpari 13. Jurnal Produksi Tanaman, 1(2), 52-60. 
Darwanto, D. (2010). Analisis Efisiensi Usahatani Padi Di Jawa Tengah (Penerapan Analisis Frontier). Jurnal Organisasi Dan Manajemen, 6(1), 46-57.

Djojosumarto, P. (2008). Panduan lengkap pestisida \& aplikasinya. Jakarta: Agromedia.Effendi, B. S. (2009). Strategi pengendalian hama terpadu tanaman padi dalam perspektif praktek pertanian yang baik (good agricultural practices). Pengembangan Inovasi Pertanian, 2(1), 65-78.

Firmana, F., Nurmalina, R., \& Rifin, A. (2016). efisiensi teknis usahatani padi di kabupaten karawang dengan pendekatan data envelopment analysis (DEA). Paper presented at the Forum Agribisnis.

Karindah, S., Purwaningsih, A., \& Agustin, A. (2015). Ketertarikan Anaxipha longipennis Serville (Orthoptera: Gryllidae) terhadap beberapa jenis gulma di sawah sebagai tempat bertelur. Jurnal Entomologi Indonesia, 8(1), 27.

Kartiasih, F., \& Setiawan, A. (2019). Efisiensi Teknis Usaha Tani Padi di Provinsi Kepulauan Bangka Belitung. Analisis Kebijakan Pertanian, 17(2), 139-148.

Kyei, L., Foli, G., \& Ankoh, J. (2011). Analysis of factors affecting the technical efficiency of cocoa farmers in the Offinso district-Ashanti region, Ghana. American journal of social and management sciences, 2(2), 208-216.

Mandei, J. R. (2015). Efisiensi Teknis Usahatani Jagung di Kecamatan Remboken Kabupaten Minahasa. AGRI-SOSIOEKONOMI, 11(1), 28-37.

Ni'mah, N., Hariyati, Y., \& Agustina, T. (2018). ANALISIS EFISIENSI HARGA DAN BIAYA USAHATANI CABAI MERAH (CAPSIUM ANNUUM L) DI KECAMATAN WULUHAN KABUPATEN JEMBER. JSEP (Journal of Social and Agricultural Economics), 10(3), 43-52.

Rahayu, W., \& Riptanti, E. W. (2010). Analisis efisiensi ekonomi penggunaan faktor-faktor produksi pada usahatani kedelai di Kabupaten Sukoharjo. Caraka Tani: Journal of Sustainable Agriculture, 25(1), 119-125.

Rao, D. P., \& Battese, G. E. (1998). An introduction to efficiency and productivity analysis: Kluwer Academic Publishers Boston.

Setyawati, I. K., \& Wibowo, R. (2019). Efisiensi Teknis Produksi Usahatani Tebu Plant Cane dan Tebu Ratoon Cane (Studi Kasus di PT. Perkebunan Nusantara X). JSEP (Journal of Social and Agricultural Economics), 12(1), 80-88.

Sinaga, S. W. (2009). Pengaruh Pemberian Insektisida Nabati Terhadap Serangan Hama Polong Pada Tanaman Kedelai (Glycine max L. Merill) Di Lapangan. Universitas Sumatera Utara Medan.

Thamrin, S. (2016). Efisiensi teknis usahatani kopi arabika di Kabupaten Enrekang. Ilmu Pertanian (Agricultural Science), 18(2), 92-97.

Wibisono, H., \& Susilowati, I. (2011). Analisis Efisiensi Usahatani Kubis (Studi Empiris Di Desa Banyuroto Kecamatan Sawangan Kabupaten Magelang). Universitas Diponegoro. 